\title{
$\mathrm{SMC}$ 複合材料の破壊じん性と微視的破壊 ${ }^{\dagger}$
}

\author{
関 根 英 樹* 小沢喜 仁** 藤 田

\section{Fracture Toughness and Microfractures of a Sheet Molding Compound Composite} \\ by
}

淳***

\section{Hideki Sekine*, Yoshihito OzawA** and Jun FujITA***}

The paper is concerned with the fracture toughness and microfractures of a sheet molding compound polyester composite at room and low temperatures. Fracture toughness tests were performed by using compact tension specimens of the composite at room temperature and liquid nitrogen temperature, 77K. Acoustic emission signals were monitored during the fracture toughness tests. The microscopic observation of the fractured surfaces and the spectrum analysis of the acoustic emission signals were made in order to obtain a reasonable explanation of the fracture mechanism. The results are summarized as follows:

(1) The load-crack mouth displacement curves at liquid nitrogen and room temperatures became nonlinear at about the same load level and the maximum load observed at liquid nitrogen temperature increased by about three times that observed at room temperature. The acoustic emission activity for the specimen tested at liquid nitrogen temperature was higher than that at room temperature.

(2) The fracture toughness $K_{\mathrm{AE}}$ at liquid nitrogen temperature, obtained as the stress intensity factor which corresponds to the onset of abrupt increase of the accumulated acoustic emission energy, was extremely larger than that at room temperature.

(3) At room temperature the fracture toughness $K_{\mathrm{AE}}$ was in good agreement with the fracture toughness $K_{\mathrm{Q}}$ obtained by the $5 \%$ offset procedure of ASTM E399, and at liquid nitrogen temperature $K_{\mathrm{AE}}$ was larger than $K_{\mathrm{Q}}$.

(4) From the microscopic observation, it was found that the fracture of a sheet molding compound composite accompanies the microfractures of four types, i. e. fiber breakage, fiber debonding, resin cracking and delamination.

(5) The spectrum analysis indicated that the acoustic emission signals could be classified into three types for the specimens tested at room temperature and four types for the specimens tested at liquid nitrogen temperature. An attempt was made to assign each type of the frequency spectra to the microfracture, and the fracture mechanism of the SMC composite was discussed.

キー・ワード : SMC 複合材料, 破壞じん性, 低温, 微視的破壊, アコースティック・エミッション

\section{1 緒言}

各種の長所を有する複合材料はエネルギ開発, 宇宙 開発, 海洋開発などにおける構造物および航空機・車 両などの多岐にわたる工業分野において使用が増大し ている.なかでも短繊維強化形複合材料は近年その製 造技術の進歩により使用範囲が大きく広がっている. SMC (Sheet Molding Compound) 複合材料は繊維 含有率を高くでき，比強度がすぐれていることや量産 が可能で経済性がすぐれていることなどから，近年最 も注目されている短繊維強化形複合材料の一つである が，比較的新しい材料であるために破壊強度を含め機 械的性質に関する研究は数少ない. Gagger らはSEN (Single Edge Notch), DEN (Double Edge Notches)
および三点曲げの各試験片から SMC 複合材料の破壊 じん性值を破壊じん性試験法 ASTM E 399 そしたが って求め, これらの比較検討を行った。 また，切欠き 先端に沶いて繊維と母材との界面はく離が生じる負荷 に対応する限界応力拡大係数も設計の観点から重要な パラメータであると主張している. SMC 複合材料で は最大荷重よりはるかに小さな荷重で繊維の破断, 繊 維と母材との界面はく離抒よび母材の割れなどの微視 的破壊が生じ切欠き先端部に損傷域が形成されるが， 高荷重になるまで巨視き裂は発生しない. したがって, 繊維と母材との界面はく離が生じるときの応力拡大係 数を破壊じん性值とすると材料の破壊じん性を過小評 価することになる. 一方, Yanada らは最大荷重に対

\footnotetext{
$\dagger$ 原稿受理 昭和60年 5 月18日 Received May 18, 1985

* 正会員 東北大学工学部 仙台市荒巻字青葉, Department of Engineering Science, Tohoku University, Aramaki Aoba, Sendai

** 福島大学教育学部 福島市松川町浅川字直道, Faculty of Education, Fukushima University, Matsukawa-cho, Fukushima

*** 東北大学大学院(現在, 三菱電機(株)) 仙台市荒巻字青染, Graduate Student, Tohoku University, Aramaki Aoba, Sendai
} 
応する応力拡大係数が試験片形状によらず一定值とな ることを示し，最大荷重に対応する応力拡大係数を破 壊じん性値とした。 また，Wang らも同様に試験時の 最大荷重から SMC 複合材料のモード I ，モードII 括 よび混合モードの破壊じん性值を求めている.このよ らに SMC 複合材料の破壞じん性の評価規準は明確に 定まっていないのが現状である.

$\mathrm{AE}$ (Acoustic Emission) 法は材料の微視的破壊を 的確に検知する有力な手法としてよく知られている. 近年，著者らは各種の FRP (Fiber Reinforced Plastics）複合材料に㧺いて AE 法を併用した破壊じん性 試験を実施し，AE 法が破壊じん性の決定に有効であ ることを示した。

本研究では SMC 複合材料であるガラス繊維強化不 飽和ポリエステル積層板よりコンパクトテンション試 験片を作製し，室温および液体窒素温度で $\mathrm{AE}$ 法を併 用した破壊じん性試験を行い，得られた結果を検討し た.さらに，周波数解析結果より検知した $\mathrm{AE}$ 信号の 分類を試み, $\mathrm{AE}$ 信号と微視的破壊との対応を議論し, 破壊機構を明らかにした。

\section{2 試験片および実験方法}

本実験に用いた $\mathrm{SMC}$ 複合材料（大日本インキ $\mathrm{R}$ $\mathrm{MC}-312-25)$ は， Eガラス短繊維のチョップドストラ ンドマットに不飽和ポリエステルを含浸させ 8 層に積 層し加熱・加圧成形したものである．強化材であるチ ョップドストランドは直径 $13 \mu \mathrm{m}$ の繊維200本からな るストランドを $25 \mathrm{~mm}$ の長さに切ったものであり， アクリルシラン処理が施してある。添加剤としては触 媒, 増粘剂, 内部離型剤を使用し, 増量剤 (炭酸カル シウム）は加えていない。ガラス繊維の重量含有率は 約 $60 \%$ あ゙あ. 供試材料の室温における機械的性質を
Table I. Mechanical properties of the SMC composite at room temperature.

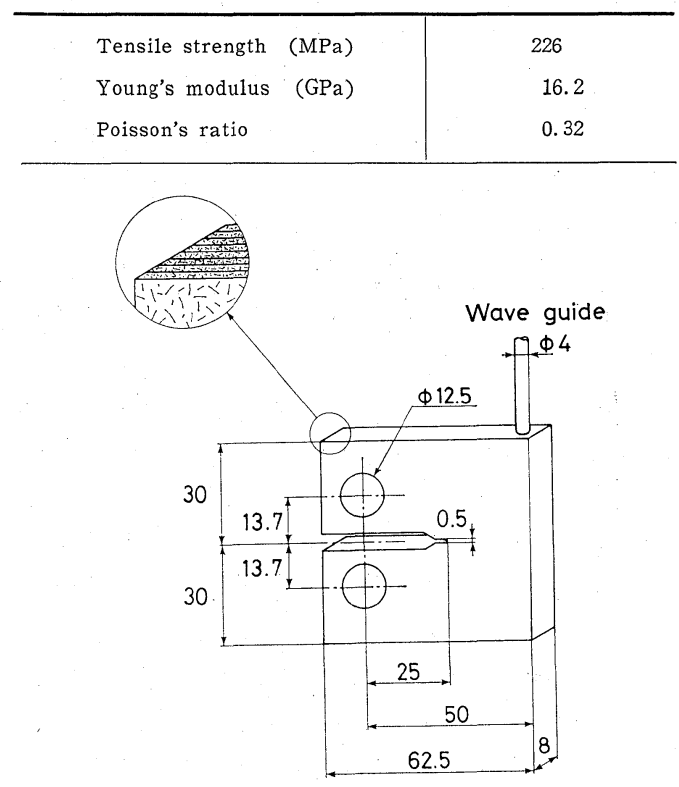

Unit : $\mathrm{mm}$

Fig. 1. Geometry of compact tension specimen.

Table I に示す. Fig. 1 は破壊じん性試験に用いたコ ンパクトテンション試験片の形状とチョップドスト ランドマットの積層方向の様子を模式的に示したも のである. 図に示すようにガラス繊維はマット面内 でランダムに配向して和り切欠き前縁は積層方向と なるよらにした. Gagger らはチョップドストランド マット材の破壊じん性值は切欠き先端半径に依存しな いことを報告している。このことに留意して本実験に 用いたコンパクトテンション試験片の切欠き先端半径

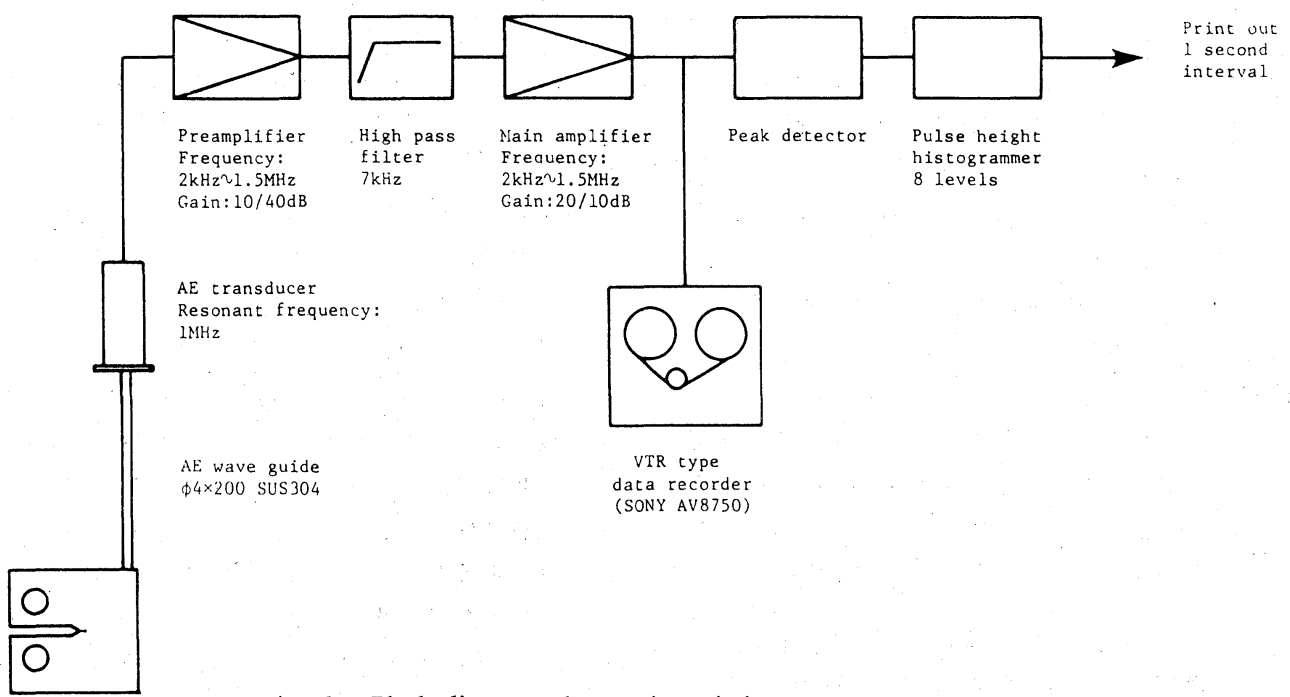

Fig. 2. Block diagram of acoustic emission measurement system. 
は $0.25 \mathrm{~mm}$ とした.

破壊じん性試験はインストロン型引張試験機を用い ASTM E $399^{22}$ に準拠しクロスヘッド速度 $0.30 \mathrm{~mm} / \mathrm{min}$ で実施した. 荷重 $P$ 执よび切欠き肩部開口変位 $V_{M}$ を $\mathrm{X}$-Yレコーダを用いて記録し，試験終了後に破壊じ 几性值を算定した. 試験中に発生する $\mathrm{AE}$ 信号のモ二 ター拉よび記録は Fig. 2 に示す $\mathrm{AE}$ 計測系を用いて 行った. AE 信号は試験片の上端部に取付けた直径 4 $\mathrm{mm}$, 長さ $200 \mathrm{~mm}$ のステンレス製ウェーブガイドを 通して共振周波数 $1 \mathrm{MHz}$ の $\mathrm{AE}$ 変換子で検出し，7 $\mathrm{kHz}$ のハイパスフィルタで試験機ノイズを除去した後, 主増幅器により総合利得 $30 \mathrm{~dB}$ 和よび $50 \mathrm{~dB}$ に増幅 した. 増幅した $\mathrm{AE}$ 信号の振幅を 2 乗演算して各 $\mathrm{AE}$ 信号のエネルギを求め，との和をとって $\mathrm{AE}$ 累積エネ ルギを算出した. 周波数解析は 7〜650 kHz の範囲で 高速フーリエ変換器を用いて行った.

低温における破壊じん性試験は試験機に低温槽を取 付け, 試験片を液体窒素 (77K) 中に完全に浸した状 態で行った. 急激な泠却による試験片の損傷をさける ために最初の 5 分間は液体窒素を少量ずつ注入して冷 却し, その後, 徐々に液量を増し試験片が完全に漬か るよらにした.この状態に 1 時間保持した後に実験を 行った.な执, 冷却時にも総合利得 $30 \mathrm{~dB}$ で $\mathrm{AE}$ 信 号の計測を行った結果, 検知された振幅 $0.2 \mathrm{~V}$ 以上の $\mathrm{AE}$ 信号の数は破壞じん性試験時の $\mathrm{AE}$ 信号の検知個 数 (3 386個) の3.5\%と非常に少なく, 冷却時に試験 片に生じた繊維と母材との界面はく離などの微視的破 壊の蓄積はほとんどないことがわかった。

\section{3 実験結果および考察}

\section{$3 \cdot 1$ 荷重-開口変位曲線と $\mathrm{AE}$.放出特性}

室温および液体窒素温度に拈ける荷重 $P$ と切欠き肩 部開口変位 $V_{M}$ との関係を Fig. 3 および Fig. 4 に 示す. 図には総合利得 $30 \mathrm{~dB}$ で検知された振幅 $0.2 \mathrm{~V}$ 以上の $\mathrm{AE}$ 信号の発生個数も併せて示してある.

室温の場合の $P-V_{M}$ 曲線は最大荷重点付近を除く と比較的線形性を示し, $\mathrm{AE}$ 信号の活性度は低い. 最 大荷重到達直前になると小さな荷重降下が生じ試験片 のコンプライアンスが増加して曲線は非線形となる.

この図には示してないが荷重降下に対応して大きなエ ネルギを持つ $\mathrm{AE}$ 信号が検知された.

液体窒素温度の場合, $P-V_{M}$ 曲線は室温の場合とほ ぼ同程度の荷重レベルから非線形性を示す．液体窒素 温度の場合は室温の場合に比べ最大荷重が約 3 倍と高 いから非線形性を示しはじめる荷重レベルを最大荷重 レベルに対する比としてみると液体窒素温度の場合に

*1 本実験で得られた結果には低温の影響のほかに, 試験片を液体窒 素に直接浸漬しているので, 液体窒素がガラス瀻維と母材との界 面に浸透するととによる影響も含まれているすのと思われる.

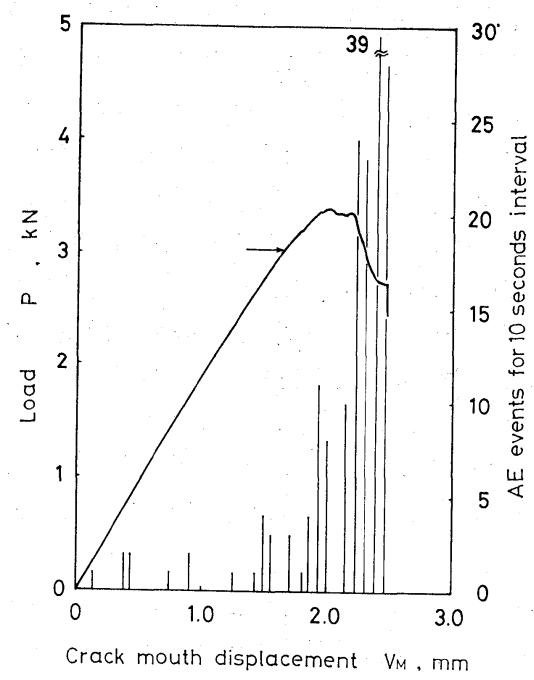

Fig. 3. $P-V_{M}$ curve and number of $\mathrm{AE}$ events for 10 second intervals for the specimen tested at room temperature.

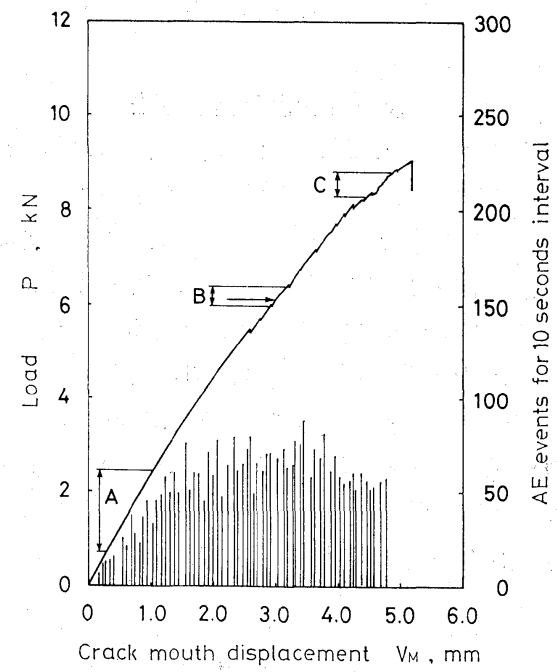

Fig. 4. $P-V_{M}$ curve and number of $\mathrm{AE}$ events for 10 second intervals for the specimen tested at liquid nitrogen temperature.

は室温の場合に比べ低い荷重レベル比のときから非線 形性を示すことになる。また，最大荷重に比べて小さ な荷重状態に叔いて, 室温の場合に最大荷重到達直前 に観察されたものと同様の荷重降下が認められた。

$\mathrm{AE}$ 信号の活性度は室温の場合のそれに比べ全般的に 高く負荷初期段階から急増する. その後, $\mathrm{AE}$ 信号の 発生個数はほぼ一定であり, 荷重降下が顕著になると 発生個数は減少する. $\mathrm{AE}$ 信号の発生個数の減少は変 位制御で実験を行っているため, 荷重降下した後それ までの最大荷重に達するまでに時間を要し，その間に Kaiser 効果により AE 信号の発生が少ないことが原 因と思われる，後述するよらに，試験片の破面観察の 
結果，室温の場合にはガラス繊維はほとんど引抜けず に破断するが，液体窒素温度の場合にはガラス繊維は ストランドの状態を保って長く引抜ける。このような 現象が生じるのは, ガラス繊維の引張強さは液体窒素 温度になると室温の場合の引張強さの約 1.5 倍増加す るために, 液体窒素温度の場合には室温でガラス繊維 が破断した負荷レベルでは破断せず，さらに界面はく 離が進展するからである。したがって，室温の場合切 欠さ先端部に形成される界面はく離等の微視的破壊が 生じた領域，すなわち損傷域は小さく，液体窒素温度 の場合には損傷域が切欠き先端部から広範囲に及ぶこ とになると考光られる.この損傷域の大ささに違いが あることから，室温の場合には $P-V_{M}$ 曲線は最大荷重 点付近まで比較的線形性を示すが，液体窒素温度の場 合には $P-V_{M}$ 曲線は最大荷重レベルに対して低い荷重 レベルのときから非線形性を示すことが理解できる. また, 液体窒素温度の場合は損傷域が広範囲に及ぶこ とから微視的破壊が多数発生すると考兄られ， $\mathrm{AE}$ 活 性度が室温の場合に比べ高くなることも理解できる. 液体空素温度の場合の最大荷重が室温の場合の最大荷 重に比べて約 3 倍高くなったが,このことに関する定 性的な説明は以下のと和りである。ガラス緎維と母材 との界面はく離に伴う $\mathrm{AE}$ 信号のェネルギを検討する と, 液体窒素温度の場合は室温の場合に比べて若干高 い。したがって, 液体窒素温度になると界面はく離強 度は若干増すものと思われる。ささらに, 前述したよう に, 液体窒素温度の場合には室温の場合に比べガラス 䋐維の引張強さが增し損傷域が大きくなる，結局, 液 体窒素温度の場合には損傷域に拈いて全体として高荷 重を支壳ることになり, 最大荷重は室温の場合に比べ 非常に高くなる。

\section{$3 \cdot 2$ 破壊じん性}

緒言でも述べたように SMC 複合材料の破壊じん性 值の規準として次の三つが挙げられる.

（1）ASTM E399 飞基づてて荷重-開口変位曲線上 の $5 \%$ オフセット荷重から算出される破壊じん性值

（2）試験時の最大荷重から算出される破壊じん性値

（3） $\mathrm{AE}$ 累積エネルギの急増開始荷重から算出され る破壊じん性値

SMC 複合材料の場合は，一般に $5 \%$ オフセット荷 重では切欠き先端部に損傷域が形成され巨視き裂は発 生しない，しかし，規準(1)は試験片のコンプライアン スの変化から $5 \%$ オフセット荷重，すなわら巨視き裂 が $2 \%$ だけ進展した場合に対応する荷重を求め，これ から破壊じん性值を算出するものである. 規準(2)は最 大荷重を用いて巨視的な不安定破壊に対する破壊じん

*2 定量的な議論は損賃域の生成を含めた応力の再分配に関する数值 解析を待たなりればならない。
性值を決定するものである，規準(3)は巨視的な破壊を 直接的に意味しない微視的破壊に着目したものである。 SMC 複合材料では微視的破壊が負荷初期段階でも存 在するが，規準(3)は微視的破壞の累積した損傷域が急 速に拡大し始める荷重に対する応力拡大係数を破壊じ し性值とするものである。本報に打いては規準(3)によ り破壊じん性值を求め，さらに，規準(1)により求めた 破壊じん性值との比較検討も行った.

Fig. 5 および Fig. 6 は，それぞれ室温および液体 窒素温度の場合に総合利得 $30 \mathrm{~dB}$ で検知した $\mathrm{AE}$ 信 号の $\mathrm{AE}$ 累積エネルギ $\sum E_{\mathrm{AE}}$ と応力拡大係数 $K$ との 関係を両対数表示したものである.両図とも $\log \sum E_{\mathrm{AE}}$

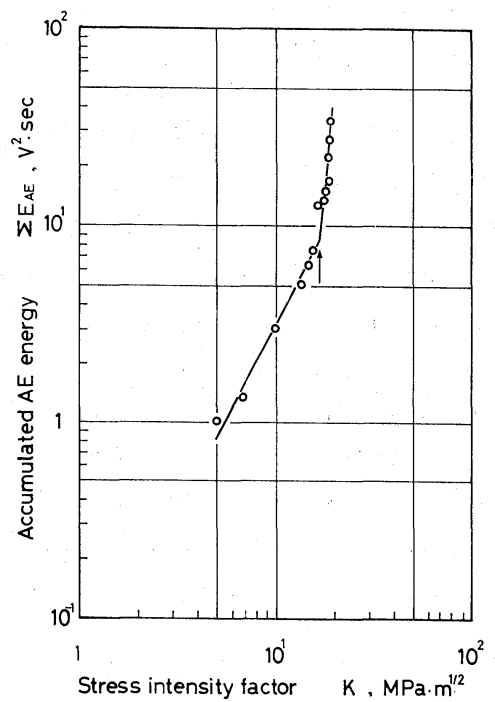

Fig. 5. $\Sigma E_{\mathrm{AE}}-K$ diagram for the specimen tested at room temperature.

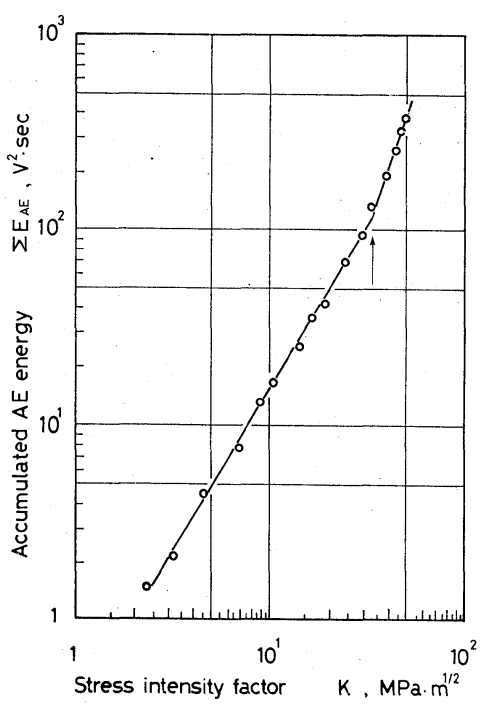

Fig. 6. $\Sigma E_{\mathrm{AE}^{-}} K$ diagram for the specimen tested at liquid nitrogen temperature. 
と $\log K$ の関係は 2 直線近似が可能であり, 2 直線 の交点 (矢印) すなわら $\mathrm{AE}$ 累積エネルギの急増開始 点が存在することがわかる。 $\mathrm{AE}$ 信号は微視的破壊に 伴って放出されるので, $\sum E_{\mathrm{AE}_{\mathrm{E}}}-K$ 線図に現れる $\mathrm{AE}$ 累積エネルギの急増は微視的破壞の累積した損傷域の 急速な拡大に対応していると考光られる. Fig. 5 和よ び Fig. 6 の $\sum E_{\mathrm{AE}}-K$ 線図の $\mathrm{AE}$ 累積エネルギの急 増開始点の応力拡大係数から破壊じん性值 $K_{\mathrm{AE}}$ 劣求 わ, この $K_{\mathrm{AE}}$ 值に対応する荷重を Fig. 3 和よび Fig. 4に矢印で示した. 得られた室温および液体窒素温度 の場合の $K_{\mathrm{AE}}$ 值を Table II K示す. 液体窒素温度 の場合の $K_{\mathrm{AE}}$ 值は室温のそれに比べ非常に大きい。 母材の引張強さは低温になると室温の場合の $2 \sim 3$ 倍 程度高くなると推測されるが，ガラス繊維の引張強さ に比べると非常に小さいから，液体窒素温度で破壞じ 九性值が増大寸る主要因子はガラス瀻維の引張強さの 増大で斿ると考えられる。 Cameron が測定した室温 执よび低温でのガラス繊維の引張強さを Table III に示す. Table II には $K_{\mathrm{AE}}$ 值のほかに, ASTM E 399 による $5 \%$ オフセット法から求妨 $K_{\mathrm{Q}}$ 值も示し た. 室温の場合は $K_{\mathrm{AE}}$ 值と $K_{\mathrm{Q}}$ 值とは比較的よく一 致するが，液体窒素温度の場合には $K_{\mathrm{AE}}$ 值は $K_{Q}$ 值 より高い值となった。これは液体咥素温度の場合に急 速な拡大を開始し始めたときの損傷域の大きさが室温 の場合のそれに比べ大きいことを示晙している。

Table II. Fracture toughness of the SMC composite.

\begin{tabular}{l|c|c}
\hline \multicolumn{1}{c|}{ Temperature } & $\begin{array}{r}K_{\mathrm{AE}}(\mathrm{MPa} \cdot \\
\left.\mathrm{m}^{1 / 2}\right)\end{array}$ & $\begin{array}{r}K_{\mathrm{Q}}(\mathrm{MPa} \cdot \\
\left.\mathrm{m}^{1 / 2}\right)\end{array}$ \\
\hline Room temperature & 16.8 & 17.5 \\
Liquid nitrogen temperature, 77K & 33.1 & 30.2 \\
\hline
\end{tabular}

Table III. Tensile strength of glass fibers ${ }^{8}$.

\begin{tabular}{c|c|c}
\hline Temperature & $\begin{array}{c}\text { Room } \\
\text { temperature }\end{array}$ & $\begin{array}{c}\text { Liquid nitrogen } \\
\text { temperature, 77K }\end{array}$ \\
\hline Tensile strength (GPa) & 3.79 & 5.65 \\
\hline
\end{tabular}

\section{$3 \cdot 3$ 微視的破壊と AE 信号の分類}

SMC 複合材料の破壊過程について検討するために, コンパクトテンション試験片の巨視破面の観察特よび $\mathrm{AE}$ 信号の周波数解析を行った.

室温括よび液体窒素温度に㧊いて破壊じん性試験を 行った破面写真を Fig. 7 (a)，(b)に示す. Fig.7 (a)か らわかるように窒温で央験を行った試験片においては, 平滑な面をした盘材と，破断あるいは引抜けたと考え られるガラス繊維が観察された．破面に露出したガラ

*3 総合利得 $30 \mathrm{~dB}$ て検知された $\mathrm{AE}$ 信号定もとに, 総合利得 $20 \mathrm{~dB}$ で㛟知される振幅 $0.2 \mathrm{~V}$ 以上の $\mathrm{AE}$ 信号の罢積エネルギを用い てあ $K_{\mathrm{AE}}$ 值としてほぼ同じ值が得られる。

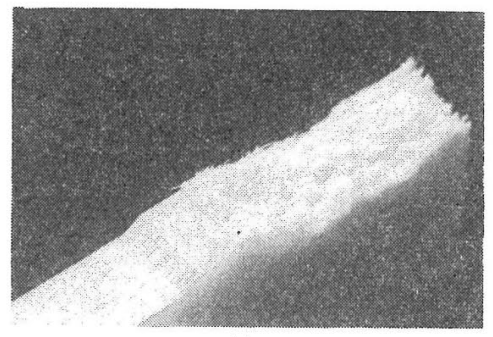

(a)

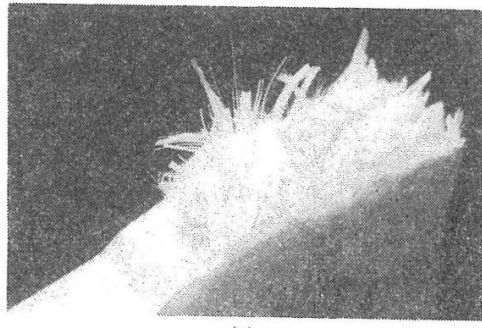

(b)

Fig. 7. Fracture surfaces of the specimens tested at room temperature (a) and at liquid nitrogen temperature (b).

ス繊維は，ストランドの状態をくずして抒りその長さ は短い。ガラス繊維の端面を拡大して観察すると, 破 断したと考えられる平滑な面をした繊維と破断せず引 抜けたと考觉られる专材の付着したものとがあった。 一方，Fig.7 (b)に示されるよらに液体䇪素温度で実験 を行った試験片に拈いては，ガラス繊維はストランド の状態を保っていてその長さも長い。また, マットの 層間はく離子観察された。 以上より, SMC 複合材料 の破偯は繊維の破断, 繊維と母材との界面はく離, 母 材の割れ，層間はく離の 4 種類の微視的破壞を伴らと 考觉られる.

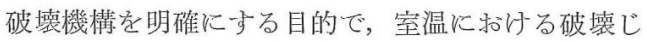
几性試験の全負荷過程物よび液体空素温度に持ける破 瓖じん性試験の負荷初期段階 (Fig. 4 の区間A)， $K_{\mathrm{AE}}$ 值に対応する荷重付近の負荷段階(区間B)および最大 荷重直前の負荷段階（区間C) に和いて総合利得 $30 \mathrm{~dB}$ で検知された AE 信号について周波数解析を行った。

検知された $\mathrm{AE}$ 信号を周波数特性に基づき整理する と，室温の場合には Fig. 8 に示すタイプI，II版よ びIIIの 3 種類に, 液体窒素温度の場合には室温の場合 のタイプI， II， IIIの他にタイプ IVを加えた 4 種類に 分類することができた.タイプIIの AE 信号はエネル ギが大きく $100 \sim 250 \mathrm{kHz}$ の範四括よび $350 \mathrm{kHz}$ 付 近に卓越した周波数成分を持っ。 $P-V_{M}$ 曲線に叔いて 観察される小さな何重降下に刘応して検知された $\mathrm{AE}$ 信号はタイプIIで方った. したがってタイプIIの $\mathrm{AE}$ 信号はガラス繊維と母材との界面はく離に対応するも のと考光られる. タイプIの $\mathrm{AE}$ 信号の周波数特性は タイプII同様の $100 \sim 250 \mathrm{kHz}$ の範国和よび 350 

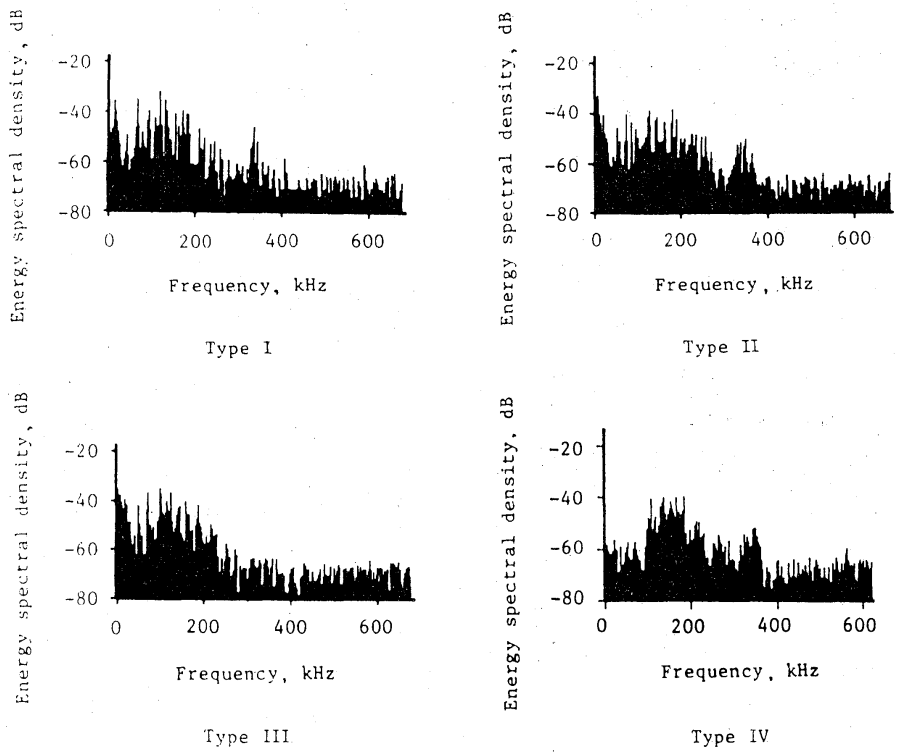

Fig. 8. Frequency spectra of $\mathrm{AE}$ signals detected from the specimens tested at room and liquid nitrogen temperatures. The spectrum of the type IV was detected only at liquid nitrogen temperature.

$\mathrm{kHz}$ 付近に卓越した周波数成分を持ち，さらに 100 $\mathrm{kHz}$ 以下にも卓越した周波数成分を持つ. 低周波数 成分が卓越した $\mathrm{AE}$ 信号は衝撃や分離破断時に観測さ れることがょく知られている。 タイプIの AE 信号の エネルギは非常に高いことと破面観察との結果から， タイプ Iの AE 信号は時間的に相前後して起きる繊維 と母材との界面はく離とガラス緘維の破断に対応する ものと考觉られる．タイプ I， II $\mathrm{AE}$ 信号は共に負 荷初期段階から検知されるが，K $K_{\mathrm{AE}}$ 值に対応する荷重 点近傍を境にして発生個数が著しく增加する.タイプ IIIの $\mathrm{AE}$ 信号は 100 250 kHz の範囲に卓越した周 波数成分を持ち， $\mathrm{AE}$ 信号のもつエネルギも小さいこ とから，母材の割れに対応するものと考兄られる．室 温扮よび液体窒素温度の場合について，全体の $\mathrm{AE}$ 信 号に占めるタイプ I とタイプ II の $\mathrm{AE}$ 信号の割合を調 べてみると，室温の場合はタイプ I の $\mathrm{AE}$ 信号の発生 率が高いが，液体窒素温度の場合はタイプ II $\mathrm{AE}$ 信 号の発生率が高い。前述したように液体窒素温度の場 合のガラス繊維の引張強さは室温の場合より高いから, 液体窒素温度の場合はガラス繊維はストランド単位で はく離して長く引抜ける。このことから液体窒素温 度の場合はタイプIIの $\mathrm{AE}$ 信号の発生率が高いことが 理解できる，液体窒素温度の場合にの及検知された夕 イプ V のAE 信号は，100〜 $200 \mathrm{kHz}$ の範围拉よび 350 $\mathrm{kHz}$ 付近に卓越した周波数成分を持つ。このタイプ の $\mathrm{AE}$ 信号は負荷後期段階の小さな荷重降下直後に観 察されて拈り，そのエネルギは高くない。したがって， このタイプNの $\mathrm{AE}$ 信号は液体窒素温度の場合に括い
ての久観察されたガラス繊維マットの層間はく離に対 応するるのと考光られる。

以上より SMC 複合材料の破壊機構は次のよう飞考 えられる.負荷初期段階に扮いても母材の割れや繊維 と母材との界面はく離，纎維の破断などの微視的破壊 が生じるが， $K_{\mathrm{AE}}$ 值に対応する荷重点近傍を境にして これらの微視的破壊は急激に進む.さらに室温と液体 窒素温度の場合を比較すると，室温の場合には時間的 に相前後して起きる繊維と母材との界面はく離と繊維 の破断が，液体窒素温度の場合には纎維の破断を伴わ ない繊維と母材との界面はく離が微視的破壊の発生個 数の上から優勢となる.

$$
4 \text { 結 言 }
$$

$\mathrm{SMC}$ 複合材料の室温拉よび低温に抢ける破壞じん 性掞よび微視的破壊を明らかにする目的で，微視的破 壊を的確に検知する有力な手法として知られている $\mathrm{AE}$ 法を併用した破壊じん性試験を室温掞よび液体窒 素温度 $77 \mathrm{~K}$ で実施し次の知見を得た。

（1）液体窒素温度の場合は荷重 $P$ 一切欠き肩部開口 变位 $V_{M}$ 曲線は室温の場合とほぼ同程度の荷重 レ心 ルから非線形性を示し，最大荷重は室温の場合の約 3 倍となる。液体窒素温度の場合の $\mathrm{AE}$ 信号の活性度は 室温の場合のそれに比べ全般的に高い。

（2）切欠き先端に抢ける微視的破壊の累積した損傷 域の急速な拡大開始を意味する $\mathrm{AE}$ 累積エネルギの急 増開始点の応力拡大係数から破壞じん性值 $K_{\mathrm{AE}}$ を得 た．液体窒素温度の場合の $K_{\mathrm{AE}}$ 值は室温の場合のそ れ比べ非常に大きい。 
（3）室温の場合は $K_{\mathrm{AE}}$ 値はASTM E399 の $5 \%$ オ フセット法により求めた $K_{\mathrm{Q}}$ 值とよく一致するが，液 体窒素温度の場合は $K_{\mathrm{AE}}$ 值は $K_{\mathrm{Q}}$ 値より高い值とな った.

（4）試験片の破面観察より $\mathrm{SMC}$ 複合材料の破壊は 繊維の破断, 繊維と母材との界面はく離, 母材の割れ および層間はく離の 4 種類の微視的破壊を伴うことを 明らかにした。

（5）周波数解析の結果に基づき $\mathrm{AE}$ 信号を室温では 3 種類に, 液体窒素温度では 4 種類に分類した. さら にそれぞれのタイプの $\mathrm{AE}$ 信号と微視的破壊との対応 を議論し，破壊機構を明らかにした。

本研究の遂行にあたり有益なご討論を頂いた東北大 学工学部新妻弘明助教授に謝意を表します。な和液体 窒素の供給は東北大学工学部低温センタによったこと を付記し謝意を表する。

（昭和60年 3 月19日 第14回 FRP シンポジウムにて講演）

\section{参 考 文 献}

1) S. K. Gagger and L. J. Broutman, ASTM STP 631, 310 - (1977).
2) ASTM Standards E399-81, "Annual Book of ASTM Standards", Part 10, p. 592 (1982) American Society for Testing and Materials.

3) H. Yanada and H. Honma, J. Mater. Sci., 18, 133 (1983).

4) S. S. Wang, E. S.-M. Chim, T.P. Yu and D.P. Goetz, J. Compos. Mater., 17, 299 (1983).

5) H. Sekine, K. Shimomura, H. Takahashi and K. Fujino, "First International Symposium on Acoustic Emission from Reinforced Composites", S3, p. 1 (1983) Soc. Plastic Industry, Inc.

6) 下村慶一, 関根英樹, 高橋秀明, 岸本正彦, 藤埜一仁, 非破壞検查, 33，520 (1984).

7) H. Niitsuma, N. Chubachi, M. Kameyama, T. Higuchi and H. Sekine, "First International Symposium on Acoustic Emission from Reinforced Composites", S5, p. 1 (1983) Soc. Plastic Industry, Inc.

8) N. M. Cameron, Glass Tech., 9, 14 (1968).

9）尾上守夫, 山口楠雄, 仲佐博裕, 佐野謙一, 磯野英二, 渡辺哲夫，“アコースティック・エミッションの基礎と 応用”（1976）コロナ社. 